\title{
PURPLE LOOSESTRIFE
}

The U.S. Fish and Wildlife Service has been alerting all personnel about a new and pernicious invader in North America. Doug Wade sent a copy of their information to George Ledingham who has noted Purple Loosestrife along Wascana in Regina. The U.S. Fish and Wildlife Service map has a dot for Saskatoon as a known location. The persistence of this plant when it becomes naturalized is documented by Edwin Way Teale in the July 1982 issue of Audubon.' The number of seeds each plant is capable of producing is almost unbelievable $(300,000)$. Mowing only serves to increase the numbers of the plant as each severed piece becomes a separate plant. It appears that the only way to be sure of destruction is to remove each plant from the site and burn them.

Purple Loosestrife (Lythrum salicaria) is an erect perennial with opposite, stalkless leaves in two ranks along a four-angled stem. It grows to $1.8 \mathrm{~m}$ tall with long spike-like arrangements of flowers that grow in the axils of bracts. The flowers are bright magenta and could look like fireweed at a distance, except that the loosestrife is a wetland herb. It can be very beautiful in expanses along the margins of streams but the rate at which it spreads and the fact that it can displace the native vegetation make it imperative to destroy it before it can become established here.

Gardeners take care -- there are horticultural varieties of this species (including a red flowered one) and it has been praised as a honey plant for naturalization. Anyone who prizes the native vegetation of our wetlands should be ready to help them in the fight against this unrelenting weed.
1 TEALE, EDWIN WAY. 1982. Stems beyond counting, flowers unnumbered. Audubon 84(4): 38-43.

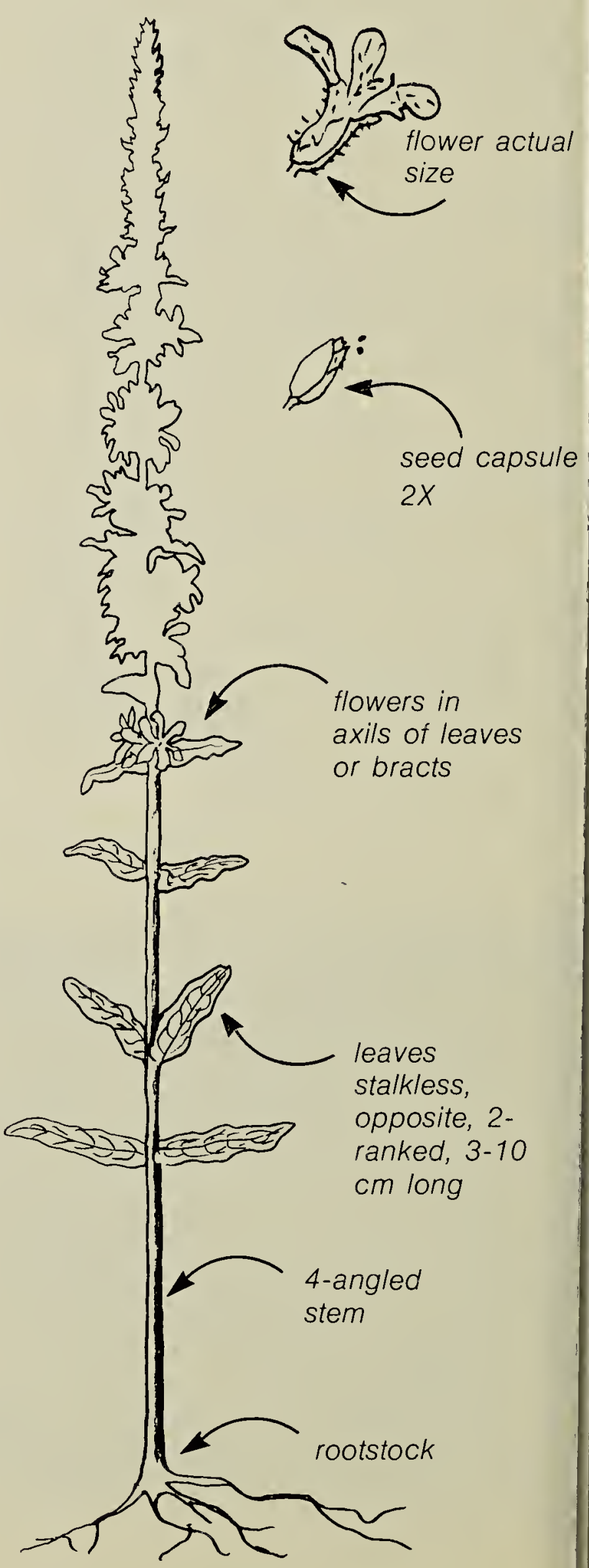

